\title{
Ultrasonographic assessment of spleen, kidney and liver size in licensed football players
}

\author{
Mehmet Demir ${ }^{1}$, Murat Baykara ${ }^{2}$, Tolga Yiğitkanlı ${ }^{3}$, Adem Doğaner ${ }^{4}$, Mustafa Çiçek $^{1}$, \\ Nurten Akkeçeci ${ }^{5}$, Atilla Yoldaş ${ }^{1}$ \\ ${ }^{1}$ Department of Anatomy, School of Medicine, Kabramanmaraş Siitçii İmam University, Kahramanmaraş, Turkey \\ ${ }^{2}$ Department of Radiology, School of Medicine, Kahramanmaraş Sïtçii İmam University, Kahramanmaraş, Turkey \\ ${ }^{3}$ Department of Radiology, Kilis State Hospital, Kilis, Turkey \\ ${ }^{4}$ Department of Biostatistics, School of Medicine, Kahramanmaraş Siitçii İmam University, Kabramanmaraş, Turkey \\ ${ }^{5}$ Department of Physiology, School of Medicine, Kahramanmaraş Siitçii Imam University, Kahramanmaraş, Turkey
}

\begin{abstract}
Objectives: The aim of this study was to find out the effect of training on dimensions of spleen, kidney and liver in licensed football players.

Methods: The study group consisted of 53 licensed male football players and 52 male non-athlete controls. The visceral organ measurements were evaluated by ultrasonography. Independent samples t test and linear regression analysis were used for statistical analysis.

Results: The mean age was $22.11 \pm 3.36$ years in footballers and $22.71 \pm 3.92$ years in controls. The spleen's transverse axis length $(4.89 \pm 0.52 \mathrm{~cm})$ and liver's anteroposterior length $(11.9 \pm 2.35 \mathrm{~cm})$ were significantly higher in the footballers compared to the controls $(4.42 \pm 0.65 \mathrm{~cm}$ and $10.39 \pm 1.9 \mathrm{~cm} ; \mathrm{p}<0.001$ and $p<0.001$; respectively). However, the lengths of the long axis of the right kidney $(10.3 \pm 0.86 \mathrm{~cm})$, long axis of the left kidney $(10.4 \pm 0.77 \mathrm{~cm})$ and the transverse axis length of the right kidney $(4.05 \pm 0.57 \mathrm{~cm})$ were significantly lower in the footballers compared to the controls $(10.69 \pm 0.68 \mathrm{~cm}, 10.97 \pm 0.68 \mathrm{~cm}, 4.35 \pm 0.74$ $\mathrm{cm} ; \mathrm{p}=0.012, \mathrm{p}<0.001, \mathrm{p}=0.02$; respectively). Furthermore, weekly training time was negatively correlated with transverse axis lengths of the right kidney (Beta=0.656; $\mathrm{p}<0.001$ ) and of the left kidney (Beta=-0.275; $\mathrm{p}=0.042$ ).

Conclusion: We consider that knowing the normal sizes of the visceral organs of footballers will be useful in determining the appropriate diagnosis and treatment and in accelerating the footballers to come back to competitions.
\end{abstract}

Keywords: football players, kidney, liver, spleen, ultrasonography

Anatomy 2018;12(2):83-89 @2018 Turkish Society of Anatomy and Clinical Anatomy (TSACA)

\section{Introduction}

Football game is one of the most popular sports in the world. Modern football game requires strength, power, and speed from players. ${ }^{[1]}$ Intensive training programs cause significant alterations in various tissues from microscopic to macroscopic scales. These alterations have been attributed to increased metabolic rate of striated muscle..$^{[2]}$ Internal organs such as liver and kidney respond to increased demand by functional alterations. ${ }^{[2,3]}$ For instance, the responses of liver to increased demand due to sportive performance are increased glucose synthesis and glycogen degradation, caused by fall in insulin and rise in glucagon blood levels. ${ }^{[3]}$ Exercise induces significant decrease in renal plasma flow, glomerular filtration rate and consequently diminished urine output as well. ${ }^{[4,5]}$

In many diseases, the size and morphology of these visceral organs also undergo significant changes. Perceived findings with different viral illness are splenomegaly, hepatomegaly and renomegaly. ${ }^{[6]}$ The knowledge of the normal range of values of the various viscera is of importance in identification of early pathological changes, treatment and may prove very useful in making clinical management decisions regarding safe return to competitions. ${ }^{[6]}$ Physical examination, such as palpation or percussion might be lacking to identify 
these changes. ${ }^{[7]}$ Ultrasonography (USG) is a straightforward and solid approach to evaluate visceral organs with non-ionizing radiation. Another advantage is that it is available even in prime healthcare units. ${ }^{[8]}$

The aim of this study was to find out the effect of training on dimensions of spleen, kidney and liver in football players. There are few studies in the literature on the visceral organ dimensions of athletes in various branches. ${ }^{[6,9-14]}$ Other studies mainly aimed to create reference values in healthy adults. ${ }^{[8,15-26]}$ To our knowledge, this is the first study that has evaluated spleen, kidney and liver dimensions in the football players.

\section{Materials and Methods}

Our study group consisted of 53 licensed football players, who were 18 years old or above, and playing in a football club in Kahramanmaraş or its nearby cities for at least five years. These players trained regularly for at least $5 \mathrm{~h}$ a week. 52 healthy men who did not perform any physical activity were included to the study as controls. The liver, spleen and both kidney measurements of the football players and the control group were evaluated using US. Body mass index (BMI) of every subject was calculated to determine obesity based on World Health Organization (WHO) obesity classification. BMI ranges were as follows; underweight: under $18.5 \mathrm{~kg} / \mathrm{m} 2$; normal weight: $18.5 \mathrm{~kg} / \mathrm{m}^{2}$ to $24.99 \mathrm{~kg} / \mathrm{m}^{2}$; overweight: $25 \mathrm{~kg} / \mathrm{m}^{2}$ to $30 \mathrm{~kg} / \mathrm{m}^{2}$; and obese: over $30 \mathrm{~kg} / \mathrm{m}^{2}$. The study was approved by the Clinical Research Ethics Committee of Kahramanmaraş Sütçü İmam University. The written informed constent was obtained from all subjects and the study was carried out in accordance with the Declaration of Helsinki. No sedation or preparation was applied before the examination. Patients who had no disease associated with the organs measured, and admitted to our radiology clinic with the request of USG for various reasons were examined. Patients with congenital anomalies or systemic diseases were not included in the examination. All organs examined were ultrasonographically in normal size, shape, and echostructure. Sonographic examinations were performed using an Aplio-400 (Toshiba, Tokyo, Japan). The Aplio-400 PVT-375BT Transducer/ Probe had been used with a $3.5 \mathrm{MHz}$ center frequency.

Liver measurements were made for the long axis and anteroposterior length. The long axis measurement of the liver was done on right mid-clavicular line while the patient was in the left lateral decubitus position. During this measurement, the longest distance between the right and left lobe extreme corners was measured by imaging the inferior vena cava and gallbladder on the same plane. The lateral segment of the left lobe was considered to be the extreme boundary in the medial, and the posterior inferior segment of the right lobe was considered to be the extreme boundary in the lateral margin (Figure 1a). The measurement for the anteroposterior length was performed on the midsagittal plane (horizontal plane passing through the xiphoid process) while the person was in the supine position. The measurement was performed at the origin points of the three hepatic veins by imaging on the same plane. In this position, the top edge of the liver under the diaphragm was considered the uppermost border (Figure 1b). ${ }^{[27]}$
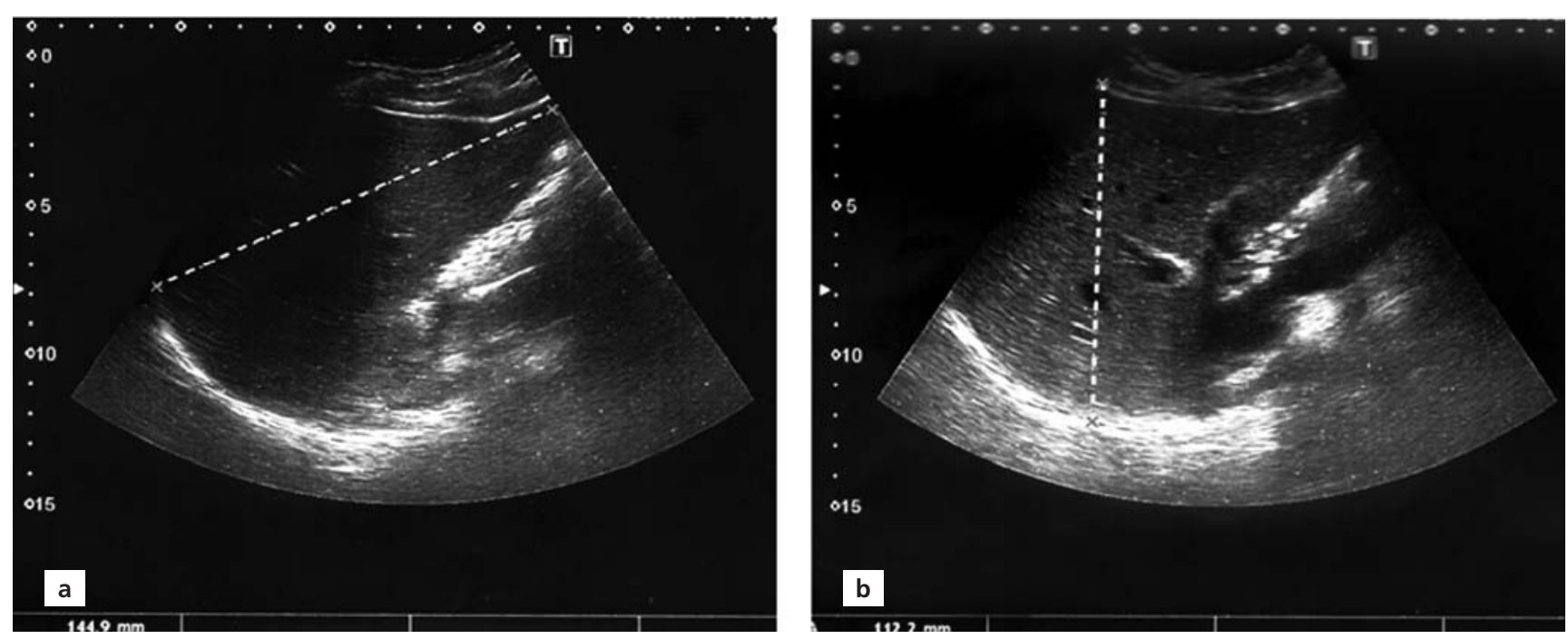

Figure 1. USG images showing measurements of (a) long axis length, and (b) anteroposterior length the liver. 
Spleen long axis measurements, on the other hand, were made by taking to the splenic hilum examination plan while the subjects were in supine position or slightly right lateral decubitus position. In this measurement, imaging of splenic vein invading splenic hilum was taken as the landmark. Long axis measurement was performed by measuring the distance between the most superomedial and inferolateral extremities of the spleen (Figure 2a). Measurement of the transverse axis of the spleen was performed by measuring the distance between the most superolateral border of the spleen and the hilum (Figure 2a). ${ }^{[27]}$

Both kidney measurements were obtained by imaging the coronal plane passing through the renal hilum while the subject was in supine position or in cubital position slightly in the right or left lateral direction. The extreme distance from the pole to the pole was considered as the long axis of the kidney (Figure 2b). Transverse axis length was obtained by measuring in such a way that it will be perpendicular to the long axis of the kidney in the hilar region (Figure 2b). ${ }^{[27]}$ All visceral organs measurements were carried out when the patient was in deep inspirium by same experienced radiologist.

Three sequential measurements were taken and the mean was calculated to ensure minimum intraobserver variation and greater accuracy and reliability of measurements.

For statistical analysis, Kolmogorov-Smirnov test was applied for the suitability of normal distribution of variables. The case and control group comparisons in normal distributed variables were performed with independ- ent samples t-test. Multivariate regression analysis was performed for the effect of training, age and BMI on visceral organ size. Autocorrelation was examined by the Durbin-Watson test. Descriptive statistics were expressed with mean \pm SD. Statistical significance level was accepted as $p<0.05$. Data were evaluated using the Statistical Package for Social Sciences (SPSS for Windows, version 22.0, IBM Corporation, Armonk, NY, USA).

\section{Results}

The study group consisted of 53 (50.5\%) licensed football players who had been keeping up their active football careers in Kahramanmaraş or its nearby cities. Controls were $52(49.5 \%)$ healthy men who did not perform any physical activity. The mean age was $22.11 \pm 3.36$ years, BMI was $23.60 \pm 1.74 \mathrm{~kg} / \mathrm{m}^{2}$, weekly training time was $7.89 \pm 1.27$ hours and the length of their football careers was $9.19 \pm 3.45$ years in the footballers. The mean age of the control group was $22.71 \pm 3.92$ years and BMI was $24.09 \pm 2.82 \mathrm{~kg} / \mathrm{m}^{2}$. There were no significant differences for age and BMI between footballers and controls ( $\mathrm{p}=0.402, \mathrm{p}=0.282$, respectively) (Table 1 ).

The spleen's transverse axis length $(4.89 \pm 0.52 \mathrm{~cm})$ and the liver's anteroposterior length $(11.9 \pm 2.35 \mathrm{~cm})$ were significantly higher in the footballers compared to controls $(4.42 \pm 0.65 \mathrm{~cm}, 10.39 \pm 1.9 \mathrm{~cm} ; \mathrm{p}<0.001, \mathrm{p}<0.001$, respectively). However, the lengths of the long axis of the right kidney $(10.3 \pm 0.86 \mathrm{~cm})$, the long axis of the left kidney $(10.4 \pm 0.77 \mathrm{~cm})$ and the transverse axis of the right kidney $(4.05 \pm 0.57 \mathrm{~cm})$ were significantly lower in the footballers compared to controls $(10.69 \pm 0.68 \mathrm{~cm}, 10.97 \pm 0.68 \mathrm{~cm}$,
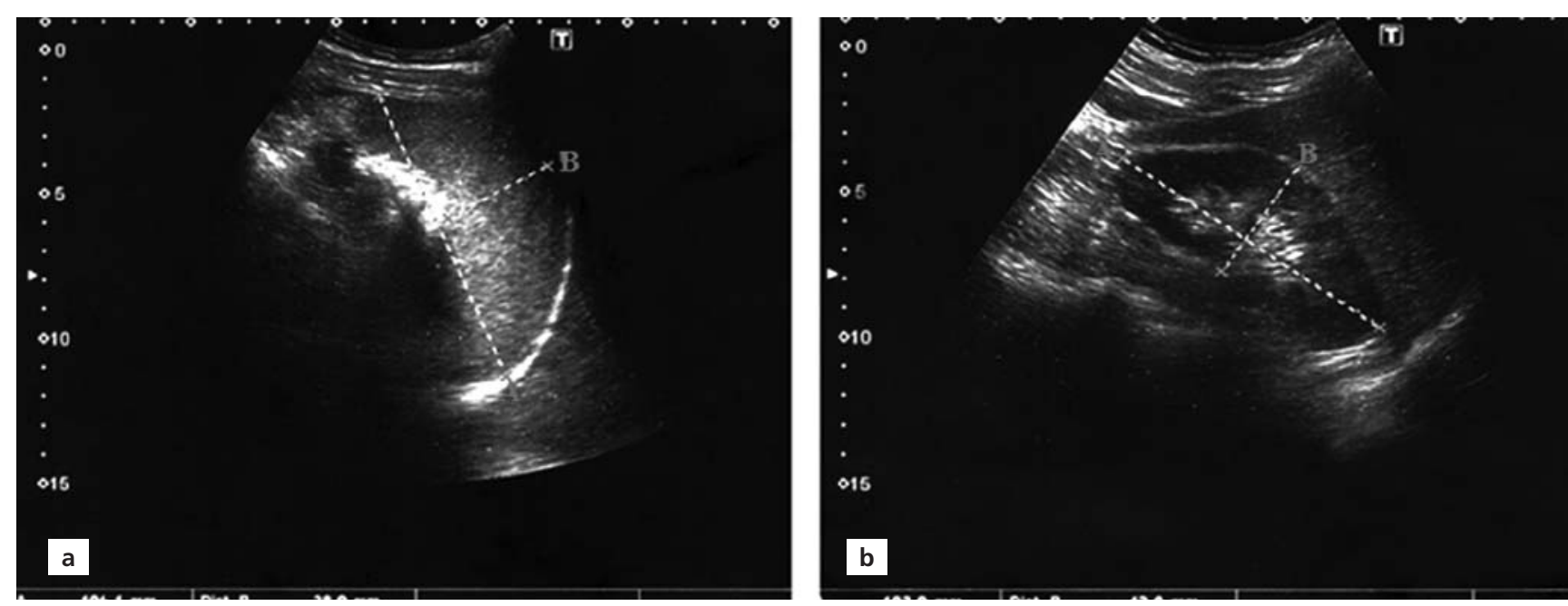

Figure 2. USG images showing measurements of (a) long axis length (dashed lines A) and transvers axis length (dashed lines B) of the spleen, and (b) long axis length (dashed lines $A$ ) and transvers axis length (dashed lines B) of the right kidney 
$4.35 \pm 0.74 \mathrm{~cm} ; \mathrm{p}=0.012, \mathrm{p}<0.001, \mathrm{p}=0.020$; respectively) (Table 2).

Weekly training time and age were positively correlated with the long axis of the spleen (Beta=0.280; Beta $=0.043, r=0.283 ; p=0.04$, respectively). Furthermore, weekly training time, age, and BMI were positively correlated with the anteroposterior length of the liver (Beta $=0.558 ; \mathrm{p}=0.001$; Beta $=0.388 ; \mathrm{p}=0.001$; Beta $=0.258$, $\mathrm{p}=0.006$, respectively). BMI was positively correlated also with the long axis of the liver (Beta=0.292; $\mathrm{p}=0.04$ ). Moreover, age was positively correlated with the long axis of the right kidney (Beta $=0.415 ; \mathrm{p}=0.003$ ). On the other hand, weekly training time was negatively correlated with transverse axis lengths of the right $($ Beta $=-0.656 ; \mathrm{p}<0.001)$ and the left kidney (Beta=-0.275; $\mathrm{p}=0.042)$ (Table 3).

\section{Discussion}

To our knowledge, this is the first study to investigate the effect of training on dimensions of spleen, kidney, and liver in football players. We found that the spleen's transverse axis length and the liver's anteroposterior length in football players were higher compared to the controls. However, the lengths of the long axis of the right kidney, the long axis of the left kidney and the transverse axis of the right kidney were lower in the footballers compared to controls. Furthermore, weekly training time was negatively correlated with transverse axis lengths of the right and left kidneys.

Kidneys are located in the retroperitoneal space at the level of T12-L3 vertebrae. Changes in the size of the kidneys are important in diagnosis and follow up of many diseases. Size of the kidneys has a particular importance in the evaluation of clinical cases such as hypertension due to renal artery stenosis, renal failure, frequent urinary tract infection complaints, and tracking renal transplant recipients. ${ }^{[15,28]}$ Buchholz et al. ${ }^{[16]}$ in their study on 194 healthy
Table 1

Descriptive data of the study population using independent samples t test.

\begin{tabular}{lccc}
\hline & $\begin{array}{c}\text { Controls } \\
(\mathbf{n}=52) \\
\text { Mean } \pm \text { SD }\end{array}$ & $\begin{array}{c}\text { Footballers } \\
(\mathbf{n}=53) \\
\text { Mean } \pm \text { SD }\end{array}$ & p \\
\hline Age (year) & $22.71 \pm 3.92$ & $22.11 \pm 3.36$ & 0.402 \\
Weight $(\mathrm{kg})$ & $72.36 \pm 10.82$ & $70.02 \pm 8.02$ & 0.211 \\
Height $(\mathrm{cm})$ & $176.87 \pm 6.74$ & $175.81 \pm 6.86$ & 0.429 \\
BMl $\left(\mathrm{kg} / \mathrm{m}^{2}\right)$ & $24.09 \pm 2.82$ & $23.60 \pm 1.74$ & 0.282 \\
Weekly training time & - & $7.89 \pm 1.27$ & - \\
(hours per week) & - & & - \\
Active football career (year) & - & $9.19 \pm 3.45$ & - \\
\hline
\end{tabular}

Table 2

Correlation of visceral organ dimensions $(\mathrm{cm})$ among the study population using independent samples t test.

\begin{tabular}{lccc}
\hline & $\begin{array}{c}\text { Controls } \\
(\mathbf{n}=52) \\
\text { Mean } \pm \text { SD }\end{array}$ & $\begin{array}{c}\text { Footballers } \\
(\mathbf{n}=53) \\
\text { Mean } \pm \text { SD }\end{array}$ & p \\
\hline Long axis length of spleen & $10.66 \pm 1.05$ & $10.91 \pm 1.28$ & 0.273 \\
Transverse axis length of spleen & $4.42 \pm 0.65$ & $4.89 \pm 0.52$ & $<0.001$ * \\
Long axis length of liver & $14.73 \pm 1.25$ & $14.41 \pm 1.03$ & 0.152 \\
Anteroposterior length of liver & $10.39 \pm 1.9$ & $11.9 \pm 2.35$ & $<0.001$ * \\
Long axis length of right kidney & $10.69 \pm 0.68$ & $10.30 \pm 0.86$ & $0.012^{*}$ \\
Transverse axis length of right kidney & $4.35 \pm 0.74$ & $4.05 \pm 0.57$ & $0.02 *$ \\
Long axis length of left kidney & $10.97 \pm 0.68$ & $10.4 \pm 0.77$ & $<0.001$ * \\
Transverse axis length of left kidney & $4.81 \pm 0.68$ & $5.03 \pm 0.56$ & 0.07 \\
\hline
\end{tabular}

${ }^{*} \mathrm{p}<0.05$

subjects (98 males, 96 females) aged between 13 and 80 years reported a left kidney length of $10.4 \pm 0.7 \mathrm{~cm}$ and a width of $4.7 \pm 0.5 \mathrm{~cm}$ for subjects aged $21-30$ years. The researchers measured the right kidney length as $10.3 \pm 0.6$

Table 3

Multivariate regression analysis of the effects of age, BMI and training time to visceral organ dimensions in football players.

\begin{tabular}{|c|c|c|c|c|c|c|c|c|}
\hline & Regression Model & Beta $\mathrm{X}_{1}$ & Beta $X_{2}$ & Beta $\mathrm{X}_{3}$ & $\mathbf{R}^{2}$ & $P\left(X_{1}\right)$ & $P\left(X_{2}\right)$ & $\mathbf{P}\left(\mathbf{X}_{3}\right)$ \\
\hline Long axis length of spleen & $Y=5.788+0.108 X_{1}+0.028 X_{2}+0.282 X_{3}$ & 0.283 & 0.038 & 0.28 & 0.193 & $0.04^{*}$ & 0.775 & $0.043^{*}$ \\
\hline Transverse axis length of spleen & $Y=5.409-0.016 X_{1}-0.002 X_{2}-0.016 X_{3}$ & -0.104 & -0.008 & -0.039 & 0.014 & 0.488 & 0.958 & 0.789 \\
\hline Long axis length of liver & $Y=11.626-0.011 X_{1}+0.172 X_{2}-0.112 X_{3}$ & -0.035 & 0.292 & -0.138 & 0.111 & 0.802 & $0.040^{*}$ & 0.326 \\
\hline Anteroposterior length of liver & $Y=9.799+0.271 X_{1}+0.346 X_{2}+1.033 X_{3}$ & 0.388 & 0.258 & 0.558 & 0.624 & $<0.001 *$ & $0.006^{*}$ & $<0.001 *$ \\
\hline Long axis length of right kidney & $Y=3.962+0.020 X_{1}+0.015 X_{2}+0.003 X_{3}$ & 0.415 & 0.108 & 0.121 & 0.233 & $0.003^{*}$ & 0.407 & 0.353 \\
\hline Transverse axis length of right kidney & $Y=5.361-0.007 X_{1}+0.051 X_{2}-0.295 X_{3}$ & -0.042 & 0.157 & -0.656 & 0.485 & 0.699 & 0.142 & $<0.001 *$ \\
\hline Long axis length of left kidney & $Y=5.978+0.057 X_{1}+0.103 X_{2}+0.113 X_{3}$ & 0.249 & 0.232 & 0.185 & 0.182 & 0.071 & 0.087 & 0.172 \\
\hline Transverse axis length of left kidney & $Y=5.139-0.039 X_{1}+0.074 X_{2}-0.121 X_{3}$ & -0.236 & 0.232 & -0.275 & 0.202 & 0.083 & 0.083 & $0.042^{*}$ \\
\hline
\end{tabular}

Multivariate regression analysis and Durbin-Watson test. R2: explanatory coefficient; $\mathrm{X} 1$ : age; $\mathrm{X} 2$ : $\mathrm{BMI} ; \mathrm{X} 3$ : training time. ${ }^{\star} \mathrm{p}<0.05$. 
$\mathrm{cm}$ and the width as $4.3 \pm 0.8 \mathrm{~cm}$. Udoaka et al. ${ }^{[17]}$ measured the left kidney length as $10.4 \pm 1.08 \mathrm{~cm}$, and width as $5.21 \pm$ $0.76 \mathrm{~cm}$, the right kidney length as $10.0 \pm 0.99 \mathrm{~cm}$ and width as $5.68 \pm 0.7 \mathrm{~cm}$. In other study performed on 140 healthy subjects (69 males, 71 females), the left kidney length of the 18-30 year-old group was reported as $9.78 \pm 0.75 \mathrm{~cm}$ and the width as $4.5 \pm 0.48 \mathrm{~cm}$; the right kidney length was reported as $9.66 \pm 0.84 \mathrm{~cm}$ and width as $4.4 \pm 0.68 \mathrm{~cm} \cdot{ }^{[18]}$ Yadav et al ${ }^{[19]}$ studied 110 healthy subjects between 15--80 years of age and measured the left kidney length has $9.97 \pm 0.77 \mathrm{~cm}$, the width as $4.01 \pm 0.95 \mathrm{~cm}$, the right kidney length as $9.88 \pm 1.01 \mathrm{~cm}$ and width as $4.06 \pm 0.63 \mathrm{~cm}$. El-Reshaid and Abdul-Fattah, ${ }^{[20]}$ in a study on 252 healthy subjects between 18-30 years of age, measured the left kidney length as $10.6 \pm 1.2 \mathrm{~cm}$ and the right kidney length as $10.75 \pm 1.3 \mathrm{~cm}$. They measured the left kidney length as $10.8 \pm 1.1 \mathrm{~cm}$ and the right kidney length as $10.5 \pm 0.9 \mathrm{~cm}$ in healthy subjects between the ages of 60 and 81 . They also reported that increasing of age does not affect the kidney length, but decreases the glomerular filtration rate. Additionally, in a study conducted in Europe, it has been reported that the normal kidney length for men should be between $9.2 \mathrm{~cm}$ and $13.3 \mathrm{~cm}$ and the normal kidney width for men should be between 3 and 7.1 $\mathrm{cm} .{ }^{[29]}$ Consistent with the studies in the literature, in our study, the control group's long axis length of the right kidney was measured as $10.69 \pm 0.68 \mathrm{~cm}$, transverse axis length was measured as $4.35 \pm 0.74 \mathrm{~cm}$; long axis length of the left kidney was measured as $10.97 \pm 0.68 \mathrm{~cm}$ and the transverse axis length was measured as $4.81 \pm 0.68 \mathrm{~cm}$. We think minor differences between the measurements in the studies depend on the race, gender, age, BMI and measurement technique used. We found that long axis and transverse axis lengths of the right kidney, and long axis length of the left kidney in football players were shorter than those of the non-athletes. It has been reported that moderate and high-intensity exercises included in the football training programs cause a marked decrease in the urine volume, the flow of the kidney plasma, the circulating blood flow in the kidneys and the renal filtration rate. ${ }^{[4,5]}$ Also, the finding of the decreased renal cortical thickness of subjects with decreased glomerular filtration rate obtained from previous studies explains why the kidney lengths of footballers are smaller than those of the control group. ${ }^{[3,30,3]}$ Furthermore, weekly training time was negatively correlated with transverse axis lengths of the right kidney and of the left kidney.

The liver is the largest organ in the human body that lies at the right hypochondriac region and it is divided into large right and small left lobes. ${ }^{[32]}$ Changes in the normal sizes of the liver are an important indicator of disease development. ${ }^{[33]}$ Knowing the normal sizes is important in surgical planning, in the tracking and treatment of the disease. ${ }^{[3,35]}$ Hepatomegaly is a term used to describe an enlarged liver beyond its normal sizes (longitudinal length $\geq 16 \mathrm{~cm}){ }^{[21,22]}$ Hepatomegaly alone is not a disease, but rather a potential indication of the process that causes it. ${ }^{[3]}$ Many researchers have reported the long axis length of the liver as $145.15 \pm 16.22 \mathrm{~mm},{ }^{[18]} 14.0 \pm 1.7 \mathrm{~cm},{ }^{[22]} 13.7 \pm 1.42$ $\mathrm{cm}^{[37]} 12.68 \pm 2.57 \mathrm{~cm}^{[32]}$ and the anteroposterior length as $11.4 \pm 1.94 \mathrm{~cm}^{[.37]}$ In our study, the long axis length of the liver was measured as $14.73 \pm 1.25 \mathrm{~cm}$ and the anteroposterior length as $10.39 \pm 1.90 \mathrm{~cm}$ in the control group in accordance with these studies. We found that the anteroposterior length of the liver in football players is longer than that of the controls. The liver is an important organ that contains enzymes that meet the increased energy needs of the body during high-density aerobic exercises. ${ }^{[10]}$ Growth in the liver size is to meet the increased energy needs of the organ. ${ }^{[12]}$ High protein diets are also given to the athletes' diet, taking into account this high energy requirement. ${ }^{[11,38]}$ It was reported that those who have been active in the American football team professionally for 2-3 years had heavier liver $(0.29 \mathrm{~kg})$, heart $(0.08 \mathrm{~kg})$ and kidney $(0.09 \mathrm{~kg})$ mass compared to the newcomers. ${ }^{[12]}$ Furthermore, weekly training time, age, and BMI were positively correlated with the anteroposterior length of the liver. Also, BMI was positively correlated with the long axis of the liver. Not taking the blood sample from football players and the control groups for various tests including the visceral organs, not measuring the portal vein diameter, and not knowing the football players' eating habits, training program, and their medical history were limitations of this study.

Spleen size is an integral part of abdominal ultrasonography because both enlarged and small spleens can be indicative of a variety of physical conditions. ${ }^{[9,23]}$ In addition, splenomegaly (longitudinal length $\geq 13 \mathrm{~cm}$ ) may be a risk factor for splenic rupture. ${ }^{[13]}$ False-positive labeling of a patient as having splenomegaly can lead to conducting unnecessary medical tests and anxiety for the athletes as well as delaying for participation in contact sports activity. ${ }^{[6,9]}$ In various studies, the long axis length of the spleen was reported as $10.76 \pm 1.84 \mathrm{~cm}^{[24]} 11.1 \pm 0.9 \mathrm{~cm}^{[25]}$ and the average as $10.9 \mathrm{~cm}^{[23]}$ for healthy adults. There are also studies reporting transverse axis length as $5.27 \pm 0.93 \mathrm{~cm}$, ${ }^{[28]}$ $4.4 \mathrm{~cm} \pm 0.5 \mathrm{~cm}^{[25]}$ and the average as $4.5 \mathrm{~cm}^{[23]}$ In accordance with these studies, we found that the control group's long axis length of the spleen was $10.66 \pm 1.05 \mathrm{~cm}$ and the transverse axis length was $4.42 \pm 0.65 \mathrm{~cm}$. In previous studies on athletes, the long axis length of the spleen was reported as $10.82 \pm 1.55 \mathrm{~cm}^{[14]} \quad 12.79 \pm 6.46 \mathrm{~cm},{ }^{[6]}$ 
$11.4 \pm 1.7 \mathrm{~cm},{ }^{[9]}$ and transverse axis length was $5.20 \pm 1.21$ $\mathrm{cm},{ }^{[14]} 5.77 \pm 6.70 \mathrm{~cm}^{[6]}$ and $5 \pm 0.8 \mathrm{~cm} .{ }^{[9]}$ Consistent with these studies, the long axis length of the spleen was measured as $10.91 \pm 1.28 \mathrm{~cm}$ and the transverse axis length was measured as $4.89 \pm 0.52 \mathrm{~cm}$ in our study. In addition, the transverse axis length of the spleen in footballers was found higher than the control group, and weekly training time and age were positively correlated with the long axis of the spleen.

\section{Conclusion}

We conclude that knowing the normal sizes of the visceral organs of footballers will be useful in determining the appropriate diagnosis and treatment and accelerating the footballers come back to competitions.

\section{References}

1. Stølen T, Chamari K, Castagna C, Wisløff U. Physiology of soccer: an update. Sports Med 2005;35:501-36.

2. Hawley JA, Hargreaves M, Joyner MJ, Zierath JR. Integrative biology of exercise. Cell 2014;159:738-49.

3. Ekun OA, Emiabata AF, Abiodun OC, Ogidi NO, Adefolaju FO, Ekun OO. Effects of football sporting activity on renal and liver functions among young undergraduate students of a Nigerian tertiary institution. BMJ Open Sport Exerc Med 2017;3:e000223.

4. Jacobs DR Jr, Sluik D, Rokling-Andersen MH, Anderssen SA, Drevon CA. Association of 1-y changes in diet pattern with cardiovascular disease risk factors and adipokines: results from the 1-y randomized Oslo Diet and Exercise Study. Am J Clin Nutr 2009;89: 509-17.

5. Weinberger M, Abu-Hasan M. Perceptions and pathophysiology of dyspnea and exercisein tolerance. Pediatr Clin North Am 2009;56:33-48.

6. McCorkle R, Thomas B, Suffaletto H, Jehle D. Normative spleen size in tall healthy athletes: implications for safe return to contact sports after infectious mononucleosis. Clin J Sport Med 2010;20: 413-5.

7. Stricker PR, Hardin BH, Puffer JC. An unusual presentation of liver laceration in a 13-yr-old football player. Med Sci Sports Exerc $1993 ; 25 ; 667-72$.

8. Megremis SD, Vlachonikolis IG, Tsilimigaki AM. Spleen length in childhood with US: normal values based on age, sex, and somatometric parameters. Radiology 2004;231:129-34.

9. Spielmann AL, DeLong DM, Kliewer MA. Sonographic evaluation of spleen size in tall healthy athletes. AJR Am J Roentgenol 2005;184:45-9.

10. Praphatsorn P, Thong-Ngam D, Kulaputana O, Klaikeaw N. Effects of intense exercise on biochemical and histological changes in rat liver and pancreas. Asian Biomedicine 2010;4:619-25.

11. Midorikawa T, Kondo M, Beekley MD, Koizumi K, Abe T. High REE in Sumo wrestlers attributed to large organ-tissue mass. Med Sci Sports Exerc 2007;39:688-93.

12. Miyauchi S, Oshima S, Asaka M, Kawano H, Torii S, Higuchi M. Organ size increases with weight gain in power-trained athletes. Int J Sport Nutr Exerc Metab 2013;23:617-23.

13. O'Connor TE, Skinner LJ, Kiely P, Fenton JE. Return to contact sports following infectious mononucleosis: the role of serial ultrasonography. Ear Nose Throat J 2011;90:E21-4.
14. Hosey RG, Mattacola CG, Kriss V, Armsey T, Quarles JD, Jagger J. Ultrasound assessment of spleen size in collegiate athletes. Br J Sports Med 2006;40:251-4.

15. Musa MJ, Abukonna A. Sonographic measurement of renal size in normal high altitude populations. Journal of Radiation Research and Applied Sciences 2017;10:178-82.

16. Buchholz NP, Abbas F, Biyabani SR, Afzal M, Javed Q, Rizvi I, Talati J. Ultrasonographic renal size in individuals without known renal disease. J Pak Med Assoc 2000;50:12-6.

17. Udoaka AI, Enyi C, Agi CE. Sonological evaluation of the liver, spleen and the kineys in an adult southern Nigerian population. Asian J Med Sci 2013;5:33-6.

18. Muthusami P, Ananthakrishnan R, Santosh P. Need for a nomogram of renal sizes in the Indian population - findings from a single centre sonographic study. Indian J Med Res 2014;139:686-93.

19. Yadav SK, Yadav R, Chakradhar S, Karn A. Measurement of renal length and width in healthy adults and their association with various parameters. International Journal of Current Research and Review 2017;9:29-32.

20. El-Reshaid W, Abdul-Fattah H. Sonographic assessment of renal size in healthy adults. Med Princ Pract 2014;23:432-6.

21. Özmen Z, Aktaş F, Özmen ZC, Almus E, Demir O. Ultrasound measurement of liver longitudinal length in a North Anatolian population: a community-based study. Niger J Clin Pract 2018;21:6537.

22. Kratzer W, Fritz V, Mason RA, Haenle MM, Kaechele V, Roemerstein Study Group. Factors affecting liver size: a sonographic survey of 2080 subjects. J Ultrasound Med 2003;22:1155-61.

23. Chow KU, Luxembourg B, Seifried E, Bonig H. Spleen size is significantly influenced by body height and sex: establishment of normal values for spleen size at US with a cohort of 1200 healthy individuals. Radiology 2016;279:306-13.

24. Serter S, Ceylan C, Tunçyürek Ö, Örgüç Ş, Pabuçcu Y. Sonographic evaluation of spleen size and prevalence of accessory spleen in a healthy male Turkish population. Turk J Hematol 2010;27:25-8.

25. Ehimwenma O, Tagbo MT. Determination of normal dimension of the spleen by ultrasound in an endemic tropical environment. Niger Med J 2011;52:198-203.

26. Singh A, Chandra N, Ansari H, Das JK. Measurement of the spleen width in relation with the height in the adults of Bihar - an ultrasonographic study. Journal of Anatomical Sciences 2016;24:13-7.

27. Doğan TH, Başak M, Karataş O, Değirmenci H, Özkurt H. 0-14 yaş arası sağlıklı çocuklarda karaciğer, dalak ve böbrek boyutlarının sonografik olarak değerlendirilmesi. Çocuk Sağlığı ve Hastalıkları Dergisi 2004;47:107-13.

28. Kumar V, Abbas A K., Fausto N, Aster JC. Robbins and Cotran pathologic basis of disease, professional edition e-book. Amsterdam: Elsevier Health Sciences; 2014.

29. Sienz M, Ignee A, Dietrich CF. Sonography today: reference values in abdominal ultrasound: aorta, inferior vena cava, kidneys. Z Gastroenterol 2012;50:293-315.

30. Mounier-Vehier C, Lions C, Devos P, Jaboureck O, Willoteaux S, Carre A, Beregi JP. Cortical thickness: an early morphological marker of atherosclerotic renal disease. Kidney Int 2002;61:591-8.

31. Hirose K, Tsuchida H, Osterby R, Gundersen HJ. A strong correlation between glomerular filtration rate and filtration surface in diabetic kidney hyperfunction. Lab Invest 1980;43:434-7.

32. Gameraddin M, Ali A, Al-radaddi M, Haleeb M, Alshoabi S. The sonographic dimensions of the liver at normal subjects compared to patients with malaria. International Journal of Medical Imaging 2015;3:130-6. 
33. Gosink BB, Leymaster CE. Ultrasonic determination of hepatomegaly. J Clin Ultrasound 1981;9:37-44.

34. Kawasaki S, Makuuchi M, Matsunami H, Hashikura Y, Ikegami T, Chisuwa H, Ikeno T, Noike T, Takayama T, Kawarazaki H. Preoperative measurement of segmental liver volume of donors for living liver transplantation. Hepatology 1993;18:1115-20.

35. Fritschy P, Robotti G, Schneekloth G, Vock P. Measurement of liver volume by ultrasound and computed tomography. J Clin Ultrasound 1983;11:299-303.
36. Axford J, O'Callaghan C. Medicine. 2nd edn. Oxford: Blackwell Science; 2004

37. Childs JT, Esterman AJ, Thoirs KA, Turner RC. Ultrasound in the assessment of hepatomegaly: a simple technique to determine an enlarged liver using reliable and valid measurements. Sonography 2016;3:47-52.

38. Pluim BM, Zwinderman AH, van der Laarse A, van der Wall EE. The athlete's heart. A meta-analysis of cardiac structure and function. Circulation 2000;101:336-44.

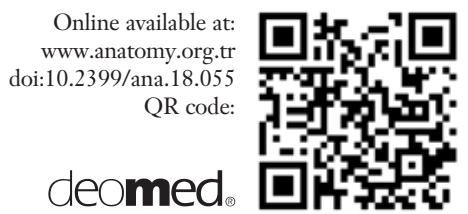

Correspondence to: Mehmet Demir, MD

Department of Anatomy, School of Medicine, Kahramanmaraş Sütçü Imam University, Kahramanmaraş, Turkey

Phone: +90 5059387311

e-mail: mdemir2779@gmail.com

Conflict of interest statement: No conflicts declared.

This is an open access article distributed under the terms of the Creative Commons Attribution-NonCommercial-NoDerivs 3.0 Unported (CC BY-NCND3.0) Licence (http://creativecommons.org/licenses/by-nc-nd/3.0/) which permits unrestricted noncommercial use, distribution, and reproduction in any medium, provided the original work is properly cited. Please cite this article as: Demir M, Baykara M, Yiğitkanlı T, Doğaner A, Çiçek M, Akkeçeci N, Yoldaş A. Ultrasonographic measurements of spleen, kidney and liver dimensions in licensed football players. Anatomy 2018;12(2):83-89. 